\title{
Indeterminate States: Transcultural, Transracial, Transgender
}

\section{Introduction}

\author{
Elizabeth Brodersen \\ IAJs; CG Jung Institute, Zürich \\ liz.brodersen@web.de \\ Pilar Amezaga \\ SUAPA; IAAP \\ pilar.amezaga@gmail.com
}

Do indeterminate states mirror and reflect creative Jungian/Post Jungian ideas about cross border migration within personal and cultural complexes as facilitators for change?

The joint IAAP/IAJS conference at the Goethe-University Frankfurt, Germany, West-end campus, held 2-5 August 2018, reflected upon the topic of Indeterminate States: transcultural, transracial, transgender within an interdisciplinary Jungian/Post-Jungian psychoanalytical framework. The five papers presented here by Kevin Lu, Robert Mitchell, Eberhard Riedel, Sulagna Sengupta and Megumi Yama offer a taste of the rich Jungian material presented.

\section{Frankfurt as Conference Venue at the Cross Roads of Europe}

In line with the view (Singer, 2010) that each city acts as a synchronistic guide to the soul of its inhabitants, Hillman (2018, pp. 17-26) stresses that soul is concerned with emotional memory and that each city signifies the presence of history within its buildings, street names, memorial statutes, and public cemeteries (ibid, p. 22). Frankfurt's long, complex multicultural trading history beginning with the Romans during the first century AD certainly engenders strong, diverse, ambivalent emotions attached to indeterminacy as a city in transit. The city experienced the stark reality of the Third Reich's brutal emphasis on racial purity and Aryan aestheticism (cf. Picot, 2001) based on nineteenth and twentieth century 'scientific' exploration of genetics which annihilated 
the vibrant cultural and economic contribution of the Jewish people living in Frankfurt who saw themselves primarily as Germans. Aryan aestheticism eliminated not only Communists, Jews, and Roma people but all mental and physically handicapped people as 'impure aberrations' of nature (Brodersen, 2019, pp. 71-75).

After the Second World War, Frankfurt Rhine Main area took in large numbers of ethnic German refugees between 1947 and 1949 expelled from their former homelands in Eastern Europe as retaliation for Nazi brutal territorial aggression. In support of victims of war torn zones, such as the Balkans during the 199os, and the recent Syrian and Middle East refugee crises, Frankfurt in its central position in Germany and at the crossroads of Europe plays an effective international role in offering shelter also on the way to other destinations.

\section{Goethe-University, Frankfurt, Home of Critical Theory}

The venue of the joint conference, Goethe-University, founded in 1914 as the first civic university in Germany, unearths much of Frankfurt's independent stand towards racism. As well as being the birthplace of the German cultural icon and polymath, Wolfgang von Goethe (1749-1832), ostensibly an ancestor of Jung, Jung's alleged antisemitism is taken seriously in Frankfurt, as the home of the Frankfurt school of Critical Theory formed during the 1920s and 1930s, by Jewish intellectuals such as Horkheimer, Adorno, Marcuse, Benjamin, Fromm and furthered by Habermas and Honneth in their emphases on recognition, inter-subjectivity, psychoanalysis and social change. In May, 2017, GoetheUniversity established the first Chair in Holocaust Studies as recognition of Frankfurt's long and respected Jewish history which includes Frankfurt's election of Ludwig Landmann, the first German Jewish mayor in 1924.

The theme Indeterminate States is well represented at the Institute for Social Research, at Goethe-University which continues Critical Theory's emphasis on analysing the socio-political factoring behind forced migration, ethnic minority injustices, gender inequalities and commodity fetishism (cf. Wiggershaus, 1994, on the history and diverse aims of the Frankfurt School). The more recent Jungian/post Jungian focus on analysis and political activism (cf. Samuels, 2001, 2015; Kiehl, Saban, Samuels, eds., 2016) reflects certain psychosocial/political activist aspects of the Frankfurt School. Briefly, (as a comparative analysis would take up more space that I can offer here) a core theme addressed by Honneth $(1988 ; 1996 ; 2012)$ stresses that societal conflict represents the struggle for recognition and embodies the negative experience of domination imbued in authoritarian systems (cf. Adorno, et al., 1950) that foster racism and mis- 
recognitions. To come to terms with such negations of subjective forms of selfrealization points to the crucial role moral recognition of the 'other' plays in grounding inter-subjectivity (Mills, 2019a). Similar to Jung's concept of individuation which stresses the need to outgrow old authoritarian, blocking, parental mechanisms of control, Critical Theory does not 'fetishize' knowledge either, considering it functional to ideological critique and social emancipation. Critical Theory transcends the methodological conundrum of 'theory/practice' by stressing their fluid interconnectedness similar to Jungian concepts of symbol formation and individuation, albeit with different emphases on unconscious processes. Mills (2019b, pp. 17-28) rightly stresses that Honneth's theory of recognition does not take into sufficient account unconscious intergenerational, affective factors that foster dysrecognition of the 'other' and simultaneously blunt empathy.

\section{3}

\section{Indeterminacy}

This timely topic ties together a key Jungian concept of 'holding the tension of the opposites' as an emergent indeterminate state, not fixed in a specific identity, whether cultural, racial or gendered within the innovative work on complex theory. The term indeterminacy refers both to common scientific and mathematical concepts of uncertainty and by implication the nature of definition or meaning (Broad, 1934). Philosophers and scientists generally try to eliminate indeterminacy from their arguments, or hide it from view (see Hardin, 2008, p. 59) since anything indeterminate is deemed unquantifiable and untestable. This relates to Popper's (1961) discussion of falsifiability in his works on the scientific method (cf. Maxwell, 1972).

Popper argues that reliable conclusions can only be drawn from replicable experiments, based on the evaluation of past evidence, since in order to establish observer agreement scientists must be able to quantify experimental evidence. Ciprut (2008) proposes that indeterminacy is foremost an ontological phenomenon, relating to the development of freewill and inter-subjectivity as an alternative to fixed, determined, causal factoring while Honderich (1988, p. 66) maintains that indeterminacy satisfies because it enhances a view of humans as morally responsible and originators free to choose the outcome of their actions. Without autonomy and free will humans are diminished as playthings and their moral agency undercut. Jung (1921, para. 533) sees indeterminism as less influenced by outer events and more by inner ideas thus giving the subject more autonomy and freedom towards outer objects. Indeterminacy defined by Mills (2019c) as a 'state of undifferentiated immediacy', consists of 
whatever we designate as a contradiction or an alterity, remaining incomplete as an indeterminate openness. This definition fits well to Jungian experiential work with symbols described as living, unfixed, unconscious structures open to new energetic arrangements.

Indeterminacy in the context of the Frankfurt conference material values speculative cognitive fluidity capable of reimagining new states that are coming into being, moving from one reference point to another in a liminal state, as yet quantifiably undefined and unknowable.

Victor Turner (1964) using the work of Van Gennep (1961) suggests that liminality belongs to inter-structural phenomena attached to rites of passage as a transitional, transformative process. Van Gennep (1961) has shown that all rites of transition are marked by three phases: separation, margin and aggregation. The first phase of separation detaches the individual/group from an earlier fixed point of containment; during the second phase of margin the individual passes through the intervening liminal anomalous stage of 'betwixt and between,' as structurally if not physically invisible as dead having no status value. The third phase is consummated in accordance to the inculcation of new societal and ethical norms.

Can we hold these indeterminate states as creative liminal manifestations pointing to new forms, integrate the shadow 'other' as potential, and allow sufficient cross border migration and fertilisation as permissible? Can we stand the process of 'not knowing' as we move into new developmental terrain whereby we question the tenets of accepted belief systems?

Jung positions the symbol as the mediatory product that develops from 'holding of the tension of the opposites' between the conscious and unconscious opposing positions, combining both in its resolution of the transcendent function that creates new cross border forms capable of restabilising the ego (1923, paras. $825-826$ ). These papers use indeterminate thinking which corresponds to Jung's definition of indirect, introverted symbolic thinking (1911-1912, paras. 4-54; 1921, para. 533) as compared to directed, hierarchical, abstracted thinking (logos) used for generalized scientific observation. The inclusion of indirect thinking gives free room for inter-subjectivity and affective responses that transform energy through symbol formation.

These papers tap into the recent work of Singer and Kimbles (2004), Kimbles (2014), Rasche \& Singer (eds.) (2016) on cultural complexes, cultural diversity, and phantom narratives that are compelled to traverse 'foreign' borders due to the painful political experiences of cultural trauma, environmental disasters, war and loss of land. From the perspective cultures facing influxes of migrants and refugees, Volkan (2017, pp.100-101) explores the cultural fear of newcomers within the concept of border psychology; he suggests that migrants and refugees 
represent difference as the 'other' who threaten psychological as well as physical borders, both perceived as protecting group integrity, identity and cohesion from disintegration.

Each of the five papers highlights a particular facet of indeterminate states moving across physical and psychic borders into new understandings of the unconscious dynamics involved.

Kevin Lu's paper on Racial Hybridity: Jungian and Post-Jungian Perspectives reflects on the birth of his two children of mixed raced heritage (British, Chinese and Canadian) and the overt racism his family has experienced which makes him sensitive to the challenges his children will face in terms of shadow projection and scapegoating. His paper explores possible contributions analytical psychology make to theorising racial hybridity. As a 'hybrid psychology' analytical psychology is well-positioned to speak to the experiences and challenges posed by multiraciality. In particular, Lu critically reflects on the hopes, fears, and fantasies that may act as a springboard to greater depth psychological reflections on the unique and equally 'typical' experience of raising mixedraced children. The physicality of being mixed race can be read as a symbolic representation of psychological liminality in a culturally diverse world. The individual uniqueness combined with the singularity of any given moment could define the flexibility of a Post-Jungian ethos. The paper itself constitutes hybridity: it explores autoethnography and racism, plus how Asians, such as Bruce Lee, have contributed to popular culture as well as the racial dynamics in professional and academic life.

Robert Mitchell's paper on Jung, Neumann and Gebser, Correlating Individuation and Integrality examines the proliferation of cross-cultural migrations and the re-culturation of previously homogeneous cultures that challenges both the cultural complex of the host nation and the individual cultural identities of immigrants. Psychological disturbances in both the individual and the culture require a re-orientation of cultural identity with a shift toward transcending cultural complexes and finding a new cultural identity in the cultural continuum. This requisite re-orientation implies the transformation of individual consciousness and of the individual's relationship to the cultural superego. Mitchell argues Individuation as a psychological process that revitalizes culture through a reorientation with an unconscious unity. Cultural philosopher, Jean Gebser, equates this reorientation with the emergence of a new structure of consciousness, integrality that transcends consciousness in the mind-ego complex. Mitchell argues that Jung's theoretical individuation process does not lead to a conclusive re-centering of the personality within a cultural identity, while Gebser's transformed integrality does not consider unconscious processes. Neumann's concept of centroversion, however, does stress individuation 
as a depth psychological process, providing the conceptual foundation for correlating individuation and integrality. It forms an identity that transcends the cultural and ego-mind sets of immigrants and their host countries.

Eberhard Riedel in his paper Collective Trauma, A Human Ecosystem Perspective develops a view of human communities as ecosystems embedded within such environments. The process evolves fieldwork in crisis areas of the eastern Democratic Republic of Congo. To explore the psychosocial and political characteristics of human ecosystems, Riedel employs a biaxial map, the Mandala of the Five Worlds which shows a dynamic mandala format of the Familial and Societal Worlds on the horizontal axis, the worlds of Nature and Mind on the vertical axis, and the Rhizome World at the core. Riedel views the rhizome world as a container and co-created field of human inheritances and codes, natural-physical and socio-cultural. Community self-states are collective aggregates that involve elements from all five spheres of the mandala. Riedel suggests that the dynamic forces of aggregation and evolution reflect a group's connectivity and tendencies: in community states of extreme collective violence and trauma, the socio-cultural and nature-mind dimensions of the map are 'unhinged': nature-nurture and humane-ethical considerations are split off from social behaviour and fractionizing fields dominate. Purposeful action seeks to loosen adhesion to the collectivity of suffering and raises awareness of the dynamics behind harmful cultural 'seizures.'

Sulagna Sengupta's paper on Indeterminate States, Transcultural Themes in Jung's India explores the trans-racial Jung-India continuum which encapsulates centuries of transcultural history. Sengupta suggests that Jung's notions about India were guided by German romanticism and enclosed many layers of cultural interactions between the two cultures. They also reflect intricate historical moments of how notions about race and culture were formed. Jung's long engagement with India held many indeterminate ideas about culture and feelings of otherness about India, its people, knowledge, religious goals etc. This paper elaborates on what formed Jung's notion of the 'cultural other' with reference to India. Jung had many divergences with Indian philosophers and spiritualists that made these transcultural exchanges more complex, for example, the concept of unconscious psyche which is absent in Indian philosophy. This paper examines these issues in understanding the notion of 'cultural other' in Jung, and the various ways by which he expressed his differences that facilitated a relational pathway between Jung and India, critical for future inquiry and dialogue.

Megumi Yama's paper Descending into the Indeterminate State between the Determinate concentrates on Jung's confrontation with images from the depth during a period of intense inner uncertainty after parting with Freud; he drew 
many mandala-like pictures. When Jung received Taoist-alchemical treatise entitled The Secret of the Golden Flower from Richard Wilhelm he realized the meaning of his mandala drawings and received confirmation of his theories about the Self. At the same time, Jung had encountered 'the East' within. Today, thanks to the publication of The Red Book (RB) and Memories, Dreams, Reflections $(M D R)$, we understand that Jung held dialogues with the 'dead.' Yama argues that the indeterminate state between a determinate culture and another is chaotic, dangerous and uncertain. With rapid globalization, people from diverse backgrounds may unwittingly step into the other culture and experience 'descending into the depth,' as Jung suffered. Yama explores Jung's inner journey and his childhood memories as movements taking place symbolically from the West to the East. Exploring further across cultures, Yama introduces a Japanese folk tale and presents clinical material, plus her experience of adolescence outside of her native culture.

\section{References}

Adorno, T. et al. (1950). The Authoritarian Personality. London \& New York: Verso, 2019. Broad, C.D. (1934). Determinism, Indeterminism, and Libertarianism. An Inaugural Lecture. Cambridge, uk: Cambridge University Press.

Brodersen, E. (2019). Taboo, Personal and Collective Representations, Origin and Positioning within Cultural Complexes. Abington, Oxon and New York: Routledge.

Ciprut, J.V. (ed.) (2008). Indeterminacy: the Mapped, the Navigable, and the Uncharted. Cambridge, MA: The mit Press.

Hardin, R. (2008). Indeterminacy and Basis Rationality. In J.V. Ciprut, (ed.) (2008). Indeterminacy: the Mapped, the Navigable, and the Uncharted. Cambridge, MA: The MIT Press, pp. 41-58.

Honneth, A. (1988). Social Action and Human Nature. Cambridge, U K: Cambridge University Press.

Honneth, A. (1996). The Struggle for Recognition. The Moral Grammar of Social Conflict. Cambridge, MA: MIT Press.

Honneth, A. (2012). The I in the We: Studies in the Theory of Recognition. Cambridge, UK: Polity Press.

Honderich, T. (1988). Mind and Brain, A Theory of Determinism, Vol. 1. Oxford: Clarendon Press.

Jung, C.G. (1911-1912/1952). Two kinds of Thinking. In Collected Works, Vol. 5 Symbols of Transformation (2nd ed.) London: Routledge and Kegan Paul, 1995.

Jung, C.G. (1921). Indeterminism versus Determinism. In Collected Works, Vol. 6. Psychological Types. (2nd ed.) London: Routledge and Kegan Paul, 1989. 
Jung, C.G. (1923). Definitions. In Collected Works, Vol. 6. Psychological Types. (2nd ed.) London: Routledge and Kegan Paul, 1989.

Kiehl, E., Saban, M., and Samuels, A. (eds.) (2016). Analysis and Activism, Social and Political Contributions of Jungian Psychology. London and New York: Routledge.

Kimbles, S. (2014). Phantom Narratives. The Unseen Contribution of Culture to Psyche. New York and London: Bowman \& Littlefield.

Maxwell, N. (1972). Philosophy of Science. A Critique of Popper's View on Scientific Method. London: University College London Archive.

Mills, J. (2019a). Recognition and pathos. In International Journal of Jungian Studies, 11 (2019) pp. 1-22, Leiden, Netherlands: Brill

Mills, J. (2019b). Dysrecognition and social pathology: New Directions in critical theory. In Psychoanalysis, Culture \& Society, Vol. 24, 1, pp. 15-30. Switzerland: Springer online.

Mills, (2019c). Psyche as Inner Contradiction. In Continental Thought \& Theory, A journal of Intellectual freedom. Vol. 3, Issue 1: Emancipation after Hegel. Online journal: Canterbury, NZ.

Picot, A. (2001). The Pure Society, from Darwin to Hitler. Trans. D. Fernbach. London and New York: Verso, 2009.

Popper, K. (1961). Poverty of Historicism. London: Routledge and Kegan Paul.

Rasche, J. and Singer, T. (eds.) (2016). Europe's Many Souls. Exploring Cultural Complexes and Identities. New Orleans: Spring Books

Samuels, A. (2001). Politics on the Couch. London: Profile Books

Samuels, A. (2015). A New Therapy for Politics? London and New York: Routledge

Singer, T. and Kimbles, S. (eds.) (2004). The Cultural Complex, Contemporary Jungian Perspectives on Psyche and Society. Hove and New York: Brunner Routledge.

Turner, V.W. (1964). Betwixt and Between: the liminal Period in Rites De Passage. In (1979). Lessa, W.A. and Vogt, E.Z. (eds.) Reader in Comparative Religion, An Anthropological Approach. 4th ed. Harvard: Harper Collins, pp. 234-243.

Van Gennep, A. (1960). Rites of Passage. Chicago: University of Chicago Press.

Volkan, V.D. (2017). Immigrants and Refugees. Trauma, Perennial Mourning, Prejudice and Border Psychology. London: Karnac.

Wiggershaus, R. (1994) trans. M. Robertson. The Frankfurt School, Its Histories, Theories and Political Significance. Cambridge, u K: Polity Press. 